\title{
Рискове при бронхоскопските манипулации в оториноларингологията
}

\author{
Цоло Цолов \\ Катедра по ушни, носни и гърлени болести, МУ София, \\ УМБАЛ „Царица Иоанна-ИСУЛ“
}

\begin{abstract}
Резюме
Авторът разглежда въпроса за рисковете и усложненията, които могат да бъдат предизвикани от неправилното и колебливо поведение на домашни лекари, от продължителните, без особен успех, консервативни терапии, от не особено прецизните бронхоскопии довели до проточване с почти цяла година лечението на деца с две разнородни чужди тела в десния главен бронх. Само настойчивостта и последова- телността в действията на педиатри и оториноларнголози - ендоскописти довеждат до трайно излекуване на децата с две различни чужди тела - зърно от леща и орехова черупка в десния главен бронх.. Авторът още веднъж набляга на изпитаната в практиката доктрина, че при всяко оправдано съмнение за чуждо тяло задължително се прибягва към бронхоскопия с обща анестезия и че за това няма противопоказания. Всяко чуждо тяло може да крие друго такова.
\end{abstract}

\footnotetext{
Summary

The author considers topic related with risks and complications of inadequate and hesitant behavior of general practitioners in clinical case of a child with two different foreign bodies in right main bronchus which was treated conservatively for almost a whole year. Only due to stubborn and contiguous actions of pediatricians and endoscopic otorhinolaryngologists the child was cured - two foreign bodies were extracted from his right main bronchus - piece of shell nut and lentils husk. Once again author emphasized that in every case where a foreign body is suspected, bronchoscopy under general anesthesia should be performed. More over - there are no contraindications to do this. One must remember that behind the foreign body a second could exist.
}

\section{Въведение}

Клиничната картина при аспирация на чужди тела при децата понякога наподобява инфекциите на дихателната система или проявите на бронхиална астма. В някои случаи това е причина за грешна или закъсняла диагноза $[1,2,3,4,11]$, излагаща на рискове живота на детето.

Попадането на чуждо тяло в дихателните пътища често се съпровожда от т. нар. „респираторна драма“.

Аспирацията на чужди тела е най-честа във възрастта до 4-5 години, като съотношението момичета: момчета е 1:2. 65\% от пациентите са на възраст между 6 месеца и 3 години. Най-честите аспирирани чужди тела са растителните. Фъстъците са приблизително $50 \%$ от всички чужди тела $[1,5,6$, $8,9,12,13]$.

\section{Патогенеза и клинична картина}

Физикалната находка след аспирацията е вариабилна и зависи от вида, размера, локализацията и степента на обтурация на лумена на бронха. При пълно запушване на просвета на дихателните пътища се развива ателектаза със скъсен перкуторен тон, отслабено везикуларно дишане. Само за няколко дни могат да се развият възпалителни промени (пневмония, ендобронхиални гранулации), което променя физикалната белодробна находка. Описаните изменения са локализирани най-често в 8-10 сегмент в долните лобове, или в средния и долен лоб в дясно. Рядко се среща ателектаза на горните белодробни дялове. 
Непълната обтурация на бронхите е най-честата находка при аспирирани чужди тела. Възникналият клапен механизъм води до сврьхраздуване на съответния бял дроб. При физикалното изследване се установява хиперсонорен перкуторен тон, отслабено везикуларно дишане и свиркащи хрипове от страната на поражението. През следващите дни бронхиалната обструкция може да бъде двустранна и да заблуди лекуващия лекар, че се касае за бронхиолит или пристъп на бронхиална астма.

Описаната клинична картина и не повлияването от лечението дават основания детето да бъде насочено за диагностична бронхоскопия, даже без анамнеза за аспирация. Трябва дебело да се подчертае и да се напомня непрекъснато на лекарското съсловие, че оправданото съмнение за чуждо тяло вече е достатъчно основание за извършването на бронхоскопия под обща анестезия и че противопоказания за това не съществуват. При продължително пребиваване на чуждото тяло в бронха, вентилният механизъм може да бъде сменен от ателектаза и развитие на значителни усложнения.

Незначителното нарушение на проходимостта на бронха, (най-често интермедиерен и лобарен) обикновено не предизвиква значими нарушения на вентилацията или изразени възпалителни промени на бронхиалната лигавица. Понякога единствена клинична проява може да бъде едностранната „бронхитна“ физикална находка с различно изразен бронхообструктивен синдром $[2,3,6,10,13,14,15]$.

Аспирацията на разнородни чужди тела едновременно или последователно при едно и също дете е рядко явление.

\section{Клиничен случай}

Представяме случай на момче с аспирация на две различни чужди тела, екстрахирани от бронхопулмоналната система при неколкократни бронхоскопии. Отнася се за дете на 2 г. и 11 месеца, Б.М.Т., от мъжки пол. Фамилна анамнеза - необременена. Нормално физическо и нервно-психическо развитие. Минали заболявания - на 1 г. и 2 мес. преболедувало от двустранна пневмония. Проведено е лечение с перорални и венозни антибиотици

На 20.05.02 - настьпила ,респираторна драма“ - след консумация на варена леща детето се задавило, появил се мъчителен пристьп на каш-

\section{МБ оториноларингология $\mathbf{\mathscr { \not }}$}

лица, завършил с повръщане. На следващия ден от дясната гръдна половина на детето се чувало „свирене“.

На 24.05.02 - извършена бронхоскопия в Благоевград, при която е извадена от десния главен бронх обвивка от лещено зърно. След екстракцията е проведено лечение с антибиотик и метилпреднизолон с временен ефект.

От май 2002 до момента на хоспитализацията в Детска клиника на МБАЛ „Александровска“ - задържаща се бронхиална обструкция, поизразена в дясната гръдна половина, не повлияваща се от обичайното лечение.

Две седмици преди постъпването в клиниката - повишило температура до $38,5^{\circ}$, кашлицата станала по-честа и по-мъчителна, „свиркащото“ дишане било по-изразено. Проведено лечение с Оспексин $^{\circledR}$ - без ефект.

На направената рентгенография на белите дробове - данни за пневмония вдясно (фиг. 1).

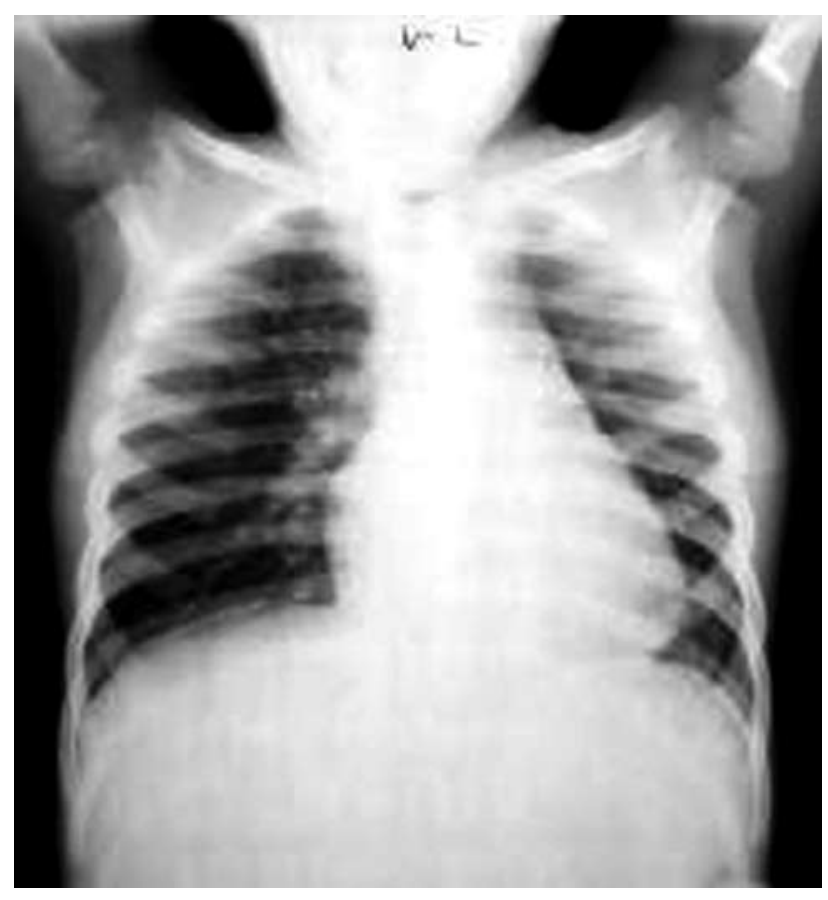

Фиг. 1. Изразено пневмонично огнище в дясната гръдна половина.

С оглед на персистиращата кашлица и не повлияваща се бронхиална обструкция детето е насочено към Детска клиника - София за консултация и лечение.

При постъпването детето беше в задоволително общо състояние, с рядка дразнеща кашлица, без белези на вентилаторна недостатьчност. Бели дробове - леко хиперносорен перкуторен тон в дясната гръдна половина, където дишането беше отслабено везикуларно, удължен експириум и 
пръснати сухи свиркащи хрипове двустранно. От лабораторните изследвания: хемограма, гърлен секрет, урина - без патологична находка. Рентгенография на белите дробове - от 16.03.03 - бронхит с обструкция.

На 17.03.2003 г беше извършена бронхоскопия под обща анестезия в УНГ клиника на МБАЛ „Царица Йоана“. В десния главен бронх в областта на бифуркацията и В8 се видяха гранулации, лигавицата на бронхиалното дърво бе зачервена, с оскъдно количество слузест секрет. Чуждо тяло в трахеобронхиалната система не се установи. На 18.03.2003 г. поради засилена бронхиална обструкция се провежда лечение с Вентолин ${ }^{\circledR}$ инхалаторно с небулизатор, метилпреднизолон и антихистаминов препарат. Клиничният ход на заболяването, персистиращите оплаквания и незначителното повлияване на бронхиалната обструкция и рентгеновата находка, наложиха провеждането след 7 дни на контролна бронхоскопия.

На 27.03.2002 при поредната ревизия на дихателните пътища под обща анестезия в десния главен бронх зад бифуркацията на В8 се визуализира чуждо тяло (парченце от черупка на орех), което се екстрахира. След екстракцията, консервативното лечение бе продължено с бърз благоприятен ефект, както по отоношение на оплакванията, така и по отношение на физикалната белодробна находка.

\section{Обсъждане}

Диагнозата на аспирираните чужди тела не е трудна при анамнеза за респираторна драма, с последващи епизоди на пристьпна кашлица и/ или „свиркащо дишане“. Не трябва да се забравя, че често близките на детето или околните не съобщават за наблюдавания от тях момент на аспирация. Персистиращата кашлица, едностранната бронхиална обструкция, не повлияването на пневмонични промени при адекватно лечение, дават основание да се обсъжда наличието на чуждо тяло в дихателните пътища. За съжаление диагнозата твърде често закъснява.

Продължителното консервативно лечение по повод на круп-синдром, трахеобронхит, бронхиална астма, белодробна туберкулоза, протрахирана и рецидивираща пневмония водят до загуба на ценно време за адекватно лечение, прогресиране на възпалителните изменения и риск от усложнения.
И при наблюдавания от нас случай екстракцията на чуждите тела е извършена след продължителен период на пристьпна мъчителна кашлица, персистираща бронхиална обструкция и пневмонична находка. Рядко е съчетанието на две съвсем различни по характеристика чужди тела - леща и парче от черупка на орех. Трудно е да се определят моментите на аспирация на двете чужди тела. Най-вероятно аспирацията на парчето от черупка на орех е последвала след аспирацията по време на хранене на лещено зърно. Въпреки негативната бронхоскопска находка по отношение на чуждо тяло при втората бронхоскопия, персистиращата респираторна симптоматика, както и наличието на гранулации наложиха да се извърши поредна бронхоскопия под обща анестезия. Екстракцията на второ чуждо тяло е още едно потвърждение на правилото, че при клиника, съмнителна за аспирирано чуждо тяло, е необходимо провеждане на бронхоскопии от опитен екип до изваждане на чуждото тяло. Бронхоскопското изследване с оптичен бронхоскоп и под обща анестезия трябва да се извърши при условия с минимален риск от компликации. Предшестващото и последващо консервативно лечение е задължителна част от лечението на пациента. Използването на флексибилен фибробронхоскоп с цел откриване на чужди тела при децата, трябва да се ограничи за диагностициране при юноши и не е препоръчително да се провежда в университетските клиники и големите болници, тук предимствата на ригидната бронхоскопия под обща анестезия са очевидни и са световна практика.

\section{Заключение}

Трябва за пореден път да подчертаем двете основни максими в практиката на педиатьра и УНГ специалиста - бронхоскопист, а именно, че при всяко оправдано съмнение за чуждо тяло в дихателните пътища се отива към бронхоскопия под обща анестезия и за това няма противопоказания и че всяко чуждо тяло може да крие под себе си и друго чуждо тяло. Продължителната, с неубедителни резултати, консерва - тивна терапия говори за колебание в лекуващите лекари и не е от полза за пациента. Търсенето и намирането на второто чуждо тяло не трябва да се възприема като неудача, а това е един успех от добрата колаборация между опитни педиатри и оториноларинголози - бронхоскописти. 


\section{Литература}

1. Георгиев Г., Ц. Цолов, М. Мелничаров: Динамика на бронхоскопиите по повод чужди тела в детската възраст за периода 1980-1985 г.Оториноларингология, XXIV, 1987,2,43-45.

2. Кабакчиев Г. и кол.: В „Детска оториноларингология“, С, МФ, 1980, 270-273.

3. Павлов Вл. и кол.: В „Учебник по УНГ болести“, С, МФ, 1988,207-210.

4. Переновска П., Ц. Цолов, М. Томова, Р. Кабакчиева: Разнородни чужди тела в дихателните пътища при децата. Оториноларингология, София, IX, 2005,1,51-54.

5. Цолов Ц., М. Мелничаров: Динамика на бронхоскопиите по повод чужди тела в дихателните пьтища за периода 1986-1990 г.Сборник резюмета На V Национален конгрес по оториноларинглогия, 30-31. Х. 1992, стр. 87.

6. Цолов Ц.: В „Ушно-носно-гърлени болести“, С, Знание ЕООД, 1998, стр. 295-301.

7. Babin E. et col.: Extraction du corps etranger bronchique de l'enfant. 105 Congres ORLF, Resumes des séances, Paris, Oct. 1998, p.143.

8. Black R.E. et al.: Bronchoscopic removal of aspirated foreign bodies in children. J. Pediatr.Surg., 1994, May, 29(5), $682-684$.

9. Burton E.M. et al.: Tracheobronchial foreign body aspiration in children. South. Med. J., 1996, Feb., 89(2), 195-198.

10. Ernst K.D., F. Mahmud: Reversible cystic dilatation of distal airways due to foreign body. South. Med. J., 1994, Mar., 87(3),404406.

11. Hughes C.A. et al.: Pediatric tracheobronchial foreign bodies: historical reviewfrom the Iohus Hopkins Hospital. Ann. Otol. Rhinol. Laryngol. 1996, Iuly, 105(7), 555-61.

12. Le Pajolec C., Bobin S.: Corps etrangers laryngotracheobronchiqu es. Dans „ORL de l'enfant“, Flamarion, 1996, 229-232.

13. Perez Prado M.G. et al.: Aspiration de cuerpos extranos. An. Esp. Ped., 1996, May, 44(5), 453 - 455.

14. Ployet M., Capelier Y.: Corps etrangers des voies aeriennes superieures de l'enfant. Rev. Prat., Paris, 1990, 40, 8, 777-780.

15. Pogorzelski A. et al.: Bronchopulmonary complications due to aspiration of foreign bodies by children. Ped. Pol., 1995, Apr., 70(4), 325-331.

16. Senkaya I., K. Sagdic et al.: Menagement of foreign body aspiration in infancy and childhood. A life threatening problem. Turk. J. Pediatr., 1997, Jul.-Sept., 39(3), 353-362.

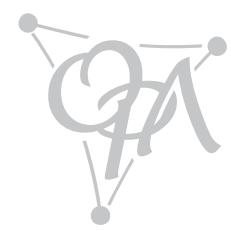

